\title{
Milan Pelc
}

Institut za povijest umjetnosti, Zagreb

\section{Nadgrobna ploča zagrebačkoga biskupa Luke od Segeda (Luke Baratina)}

\author{
Izvorni znanstveni rad - Original scientific paper \\ Primljen-Received 17.6. 2021. \\ UDK 726.8Luka od Segeda \\ DOI https://doi.org/10.31664/ripu.2021.45.03
}

\begin{abstract}
Sažetak
Nakon potresa 1880. pronadena su u podu zagrebačke katedrale tri ulomka renesansne nadgrobne ploče biskupa Luke od Segeda (Luka Baratin, 1500. - 1510.), koja su darovana Narodnom muzeju (danas Hrvatskom povijesnom muzeju) u Zagrebu. Nakon posljednjeg potresa 22. ožujka 2020. otkrivena su ispod popločenja svetišta još četiri ulomka koja bitno dopunjuju izgled i oblik biskupove ploče, potvrđujući umjetničko i materijalno jedinstvo njezine izvedbe, kao i njezinu posebnost u skupini sličnih nadgrobnih spomenika na prostoru Ugarskog Kraljevstva $i z$ tog vremena. Novi nalaz otkrio je gotovo čitav donji dio biskupova tijela u potpunom ornatu. Sad se može vidjeti da biskupu Luki na
\end{abstract}

prsima leži pacifikal s trolisnim završetcima krakova u čijoj je sredini još jedan manji, plitko klesani križ. Unjegovoj sredini uklesano je romboidno udubljenje, u kojem je vjerojatno bio učvršćen brončani umetak Kristova korpusa. Novi nalaz otkrio je još jedan važan ikonografski detalj: veliki medaljon s prikazom imago pietatis u obliku enkolpiona koji visi oko biskupova vrata. Taj motiv, kao zalog pokojnikove vjere u izbavljenje iz čistilišta, zasad je jedinstven u sepulkralnoj umjetnosti sjeverne Hrvatske, a i citavoga Ugarskog Kraljevstva. On ukazuje na to da iza ikonografske koncepcije nadgrobne ploče vjerojatno stoji sam naručitelj - biskup Luka.

Ključne riječi: zagrebački biskup Luka od Segeda (Luka Baratin), nadgrobna ploča, enkolpion, imago pietatis

Razorni potres koji je u rano jutro 22. ožujka 2020. pogodio Zagreb i okolicu nanio je velike štete zagrebačkoj katedrali. Prilikom primarnog saniranja posljedica potresa, odnosno pripreme za hitne građevinske radove, u podu apside prvostolne crkve pronađena su četiri kamena fragmenta (sl. 1) koja su odmah prepoznata kao dijelovi nadgrobne ploče zagrebačkog biskupa Luke od Segeda, poznatog i kao Luka Baratin (zagrebački biskup od 1500. do 1510.). ${ }^{1}$ Javnost je o tome ubrzo bila obaviještena putem medija. Potom je i Muzej grada Zagreba priredio prigodnu izložbu Muzejski život u doba pandemije i potresa, na kojoj su novopronađeni fragmenti fizički predstavljeni. ${ }^{2} \mathrm{Na}$ izložbi ti su fragmenti "spojeni" s reprodukcijama tri ulomka iste ploče, koja se čuvaju u Hrvatskome povijesnom muzeju. ${ }^{3}$ Poslije izložbe u Muzeju grada Zagreba ta je "instalacija" pohranjena u tzv. Domitrovićevoj kuli na Kaptolu, gdje novootkriveni fragmenti čekaju potpuno čišćenje i konzervatorsku zaštitu. ${ }^{4}$ Svakako bi bilo poželjno da se oni u budućnosti objedine s ulomcima u Hrvatskome povijesnom muzeju u cjelinu, koja bi uz potrebne restauratorske zahvate mogla vjerno dočarati stvarni izgled nadgrobne ploče biskupa Luke (sl. 2).

Tri ulomka sačuvana u Hrvatskome povijesnom muzeju, među kojima je najdojmljivija portretna glava pokojnoga biskupa, već su dulje od jednog stoljeća razmatrana u hrvatskoj i mađarskoj historiografiji. ${ }^{5}$ Neki domaći stručnjaci pripisivali su njihovu izradu Ivanu Duknoviću, no čini se da su u novije vrijeme dvojbe oko autorstva uklonjene i da je kao autor biskupove nadgrobne ploče prihvaćen talijanski kipar Johannes Fiorentinus, čija je radionica u Ostrogonu izradila niz djela, ponajviše nadgrobnih ploča, za različite naručitelje u srednjoeuropskim pokrajinama. ${ }^{6}$ Četiri nova ulomka iz katedrale bitno dopunjuju izgled i oblik biskupove ploče, potvrđujući umjetničko i materijalno jedinstvo njezine izvedbe, kao i njezinu posebnost u skupini sličnih nadgrobnih spomenika na prostoru Ugarskoga Kraljevstva iz tog vremena. ${ }^{7}$

Poslijepotresni nalaz u zagrebačkoj katedrali utoliko nam je dragocjeniji što pripada jednom od umjetnički najvrsnije 


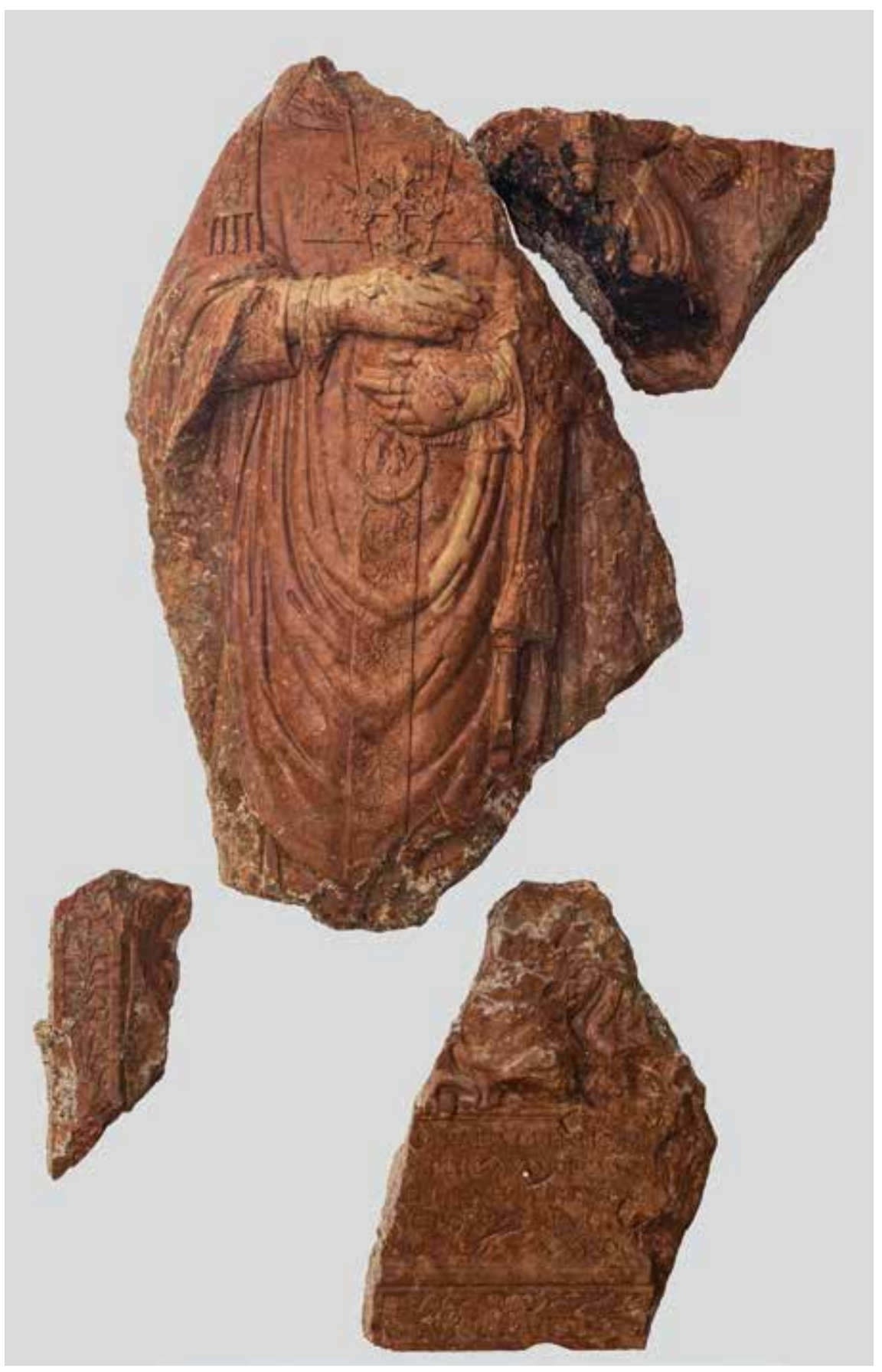

1. Novopronađeni ulomci nadgrobne ploče biskupa Luke Newly found fragments of Bishop Luka's tombstone

izrađenih nadgrobnih spomenika iz renesansnoga doba u sjevernoj Hrvatskoj. Potpunim čišćenjem kamenih ulomaka i rekonstrukcijom ploče dobit će se prvorazredni spomenik zagrebačke renesanse, koji doduše nije nastao u Zagrebu, ali ga je naručio tadašnji zagrebački biskup, osobito zaslužan za uređivanje unutrašnjosti stolne crkve. ${ }^{8}$ Tijekom svoje desetogodišnje službe na zagrebačkoj biskupskoj stolici biskup Luka dovršio je gradnju svodova u lađama katedrale koja je time konačno čitava nadsvedena. ${ }^{9} \mathrm{U}$ njegovo doba katedrala je dobila letner koji je odvajao prostor svetišta od prostora za puk. Na koru letnera postavljene su orgulje, a ispred njega u sredini podignut je novi oltar Svetoga Križa. Letner je u katedrali stajao gotovo tri stoljeća. Dijelom je uklonjen za biskupa Maksimilijana Vrhovca, a dijelom nakon potresa 1880. godine. Narudžbi biskupa Luke pripisuje se i slika Raspeća s tri ugarska vladara, pripisana furlanskom majstoru Gianfrancescu da Tolmezzu, koja se vjerojatno nalazila na oltaru Sv. Križa. ${ }^{10}$ Riznici stolne crkve biskup Luka priskrbio je nekoliko dragocjenih predmeta koji svjedoče o njegovu umjetničkom ukusu prožetom renesansnim duhom. Premda fizički možda najmanje vidljiva, njegova je vjerojatno najveća zasluga za kulturnu povijest Zagrebačke 
(nad)biskupije narudžba prvoga (i jedinoga) tiskanog misala prema obredu zagrebačke crkve. Taj misal, s grbovima kralja Vladislava Jagelovića i samoga biskupa Luke na naslovnoj stranici, tiskan je u Veneciji 1511. i raskošno opremljen drvoreznim ilustracijama. ${ }^{11}$ Osim misala biskup je 1505. dao tiskati i drugo izdanje zagrebačkog brevijara, za čije se prvo izdanje 1484. pobrinuo njegov predšasnik na zagrebačkoj biskupskoj stolici, biskup Osvald Tuz (zagrebački biskup od 1466. do 1499.). ${ }^{12}$

Biskupi Osvald i Luka bili su u bliskom doticaju s kraljevskim dvorom u Budimu u doba Matije Korvina i Vladislava Jagelovića, gdje su obnašali ugledne službe kraljevih rizničara. Boraveći često u Budimu, biskupi su dolazili u neposredan doticaj s kulturnim trendovima na dvoru i strujanjima renesansne mode koja se iz Italije širila prema rubnom području Ugarskoga Kraljevstva. Radionice umjetnika, u kojima su glavnu riječ imali talijanski majstori, oformljene za zadovoljavanje potreba kraljeve palače, primale su narudžbe i od ostalih uglednika, ponajprije od crkvenih i svjetovnih velikaša, koji su oponašali umjetnički ukus vladara i njegova dvora. ${ }^{13} \mathrm{U}$ tom sklopu kao jedan od vodećih kulturnih "trendmejkera" u duhu humanizma i renesanse toga vremena ističe se kardinal Toma Bakač, koji je nakon smrti biskupa Luke postao privremenim upraviteljem Zagrebačke biskupije. Zagrebački biskup Luka pridružio se svojim narudžbama njemu i drugim prelatima koji su držali korak s kulturnom modom na kraljevskom dvoru. ${ }^{14}$

Među umjetničkim djelima, koja još od srednjega vijeka nastaju iz želje naručitelja za osobnom reprezentacijom i trajnom memorijom, istaknuto mjesto zauzimaju nadgrobne ploče s likom pokojnika. ${ }^{15}$ Osim toga, ploča s likom preminuloga, koja pokriva njegovu posmrtnu "kuću" smještenu u blizini glavnoga oltara crkve, imala je osobitu važnost u sklopu eshatoloških očekivanja naručitelja koji je preko svojeg lika na grobnici posredno sudjelovao u liturgijskom zbivanju, sjedinjen s molitvenom zajednicom. Prema vjerovanju srednjovjekovnih ljudi pokojnikovo je mrtvo tijelo ostalo povezano sa svojom dušom na nebu, s kojom se trebalo ponovo združiti nakon posljednjeg suda. ${ }^{16}$ Nazočnost pokojnika u grobu i u zajednici in effigie povećavala je mogućnost otpuštanja kazne u čistilištu i stjecanja milosti u trenutku konačnog sjedinjenja duše s tijelom. ${ }^{17}$

Biskupi Osvald i Luka za svoje su grobnice, smještene na eminentnim mjestima u ecclesia cathedralis, dali izraditi nadgrobne ploče na kojima je prikazan njihov lik u punom ornatu s grbom i prigodnim natpisom. Te su ploče najranije opisane u rukopisu kanonika Rafaela Levakovića oko 1638. godine, koji ih je vidio u svetištu crkve. ${ }^{18}$ Vidio ih je poslije i kanonik Toma Kovačević koji je u svom Katalogu zagrebačkih biskupa, sastavljenom početkom 18. stoljeća, konstatirao da su obje nadgrobne ploče, zajedno s pločama drugih biskupa koje su se nalazile u svetištu katedrale, uklonjene prilikom postavljanja novog popločenja 1703 . godine. ${ }^{19}$ Nažalost, oni koji su naručili i nadzirali taj zahvat u svetištu katedrale nisu imali dovoljno pijeteta ni poštovanja prema svojim predšasnicima na zagrebačkoj biskupskoj stolici, pa su njihove nadgrobne ploče, umjesto da ih sačuvaju makar u zidovima

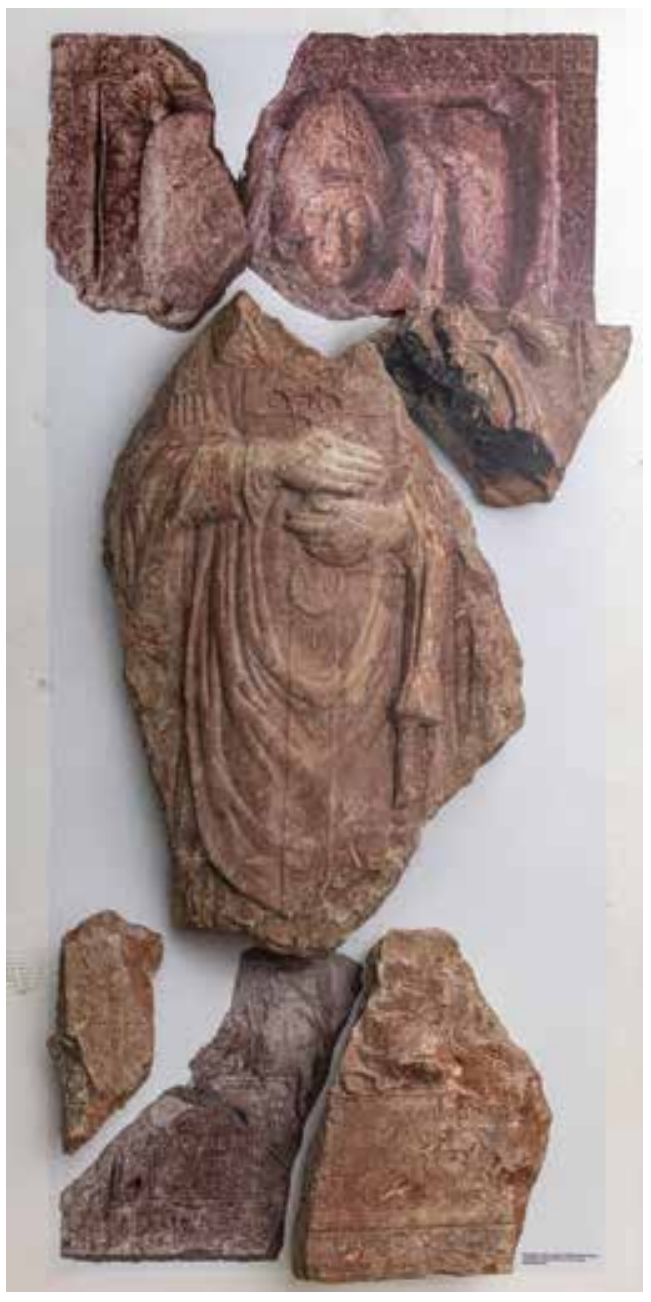

2. Rekonstrukcija nadgrobne ploče biskupa Luke sa svim pronađenim ulomcima

Reconstruction of Bishop Luka's tombstone with all the fragments found

unutrašnjosti ili vanjštine crkve, kako je često bio običaj u takvim situacijama, bez milosti pretvorili u kamenu građu koja je služila kao podloga novom popločenju. ${ }^{20}$

Grobnica biskupa Luke, položena u južnom dijelu apside kod oltara sv. Luke, nalazila se točno nasuprot grobnici biskupa Osvalda, smještenoj kraj oltara Posljednje večere na sjevernoj strani apside katedrale. ${ }^{21}$ Naime, biskup Luka dao je 1508. podići u svetištu katedrale oltar Uznesenja Blažene Djevice Marije i sv. Luke, namijenivši u ime altarije rektoru ovoga oltara zidanu kuću koju je kupio u Pešti za 1400 forinti. Uz taj oltar, kraj samoga zida, nalazila se biskupova grobnica s grobnom pločom. ${ }^{22}$ Grobna ploča biskupa Osvalda bila je, kako pišu kroničari, od bijeloga dok je ona biskupa Luke bila od crvenog "mramora". Riječ je zapravo o kvalitetnome crvenom ugarskom kamenu vapnencu koji se, kako je petrografskom analizom potvrđeno, vadio u kamenolomima gorja Gerecse blizu Ostrogona.$^{23}$ Rafael Levaković opisuje ju oko 1638. sljedećim riječima: »Pokraj zida ispred ovog oltara (misli se - sv. Luke) koji se nalazi s južne strane glavnog oltara (ad cornu epistolae altaris maioris) je grobna ploča biskupa Luke od crvenog mramora (marmoris rubei). Biskup je odjeven u pontifikalnu odjeću s pastirskim štapom ispod lijeve 
ruke. Kraj desne noge nalazi se njegov grb izliven u mjedi $\mathrm{u}$ obliku štita na kojem je grifon $s$ krunom pod nogama. ${ }^{24}$

Na ploči je uklesan sljedeći natpis:

[HIC SITV]S EST LVCAS PRAESVL VENERABIL[IS] ${ }^{25}$ ZAGRABIAE TEMPLI LVXQVE DECVSQ S[VI] ili S[ACRI $]^{26}$ QVI PIETATE PARENS NVLLI VIRTVTE SEC[VNDVS] ${ }^{27}$

ACCEPIT MERITIS ASTRA PARATA SVIS

OBIIT ANNO MDX X K(A)L. OC[TOBRIS $]^{28}$

\section{U prijevodu:}

Ovdje leži Luka, prečasni biskup.

Svetom (Svojem?) je zagrebačkom hramu bio ures i svjetlo. U pobožnosti uvijek prvi, nenadmašan u kreposti.

Zaslugama je svojim zavrijedio nagradu neba.

Umro je 22. rujna $1510 .^{29}$

Prilikom obnove katedrale nakon potresa 1880. Herman Bollé potpuno je izmijenio izgled njezina svetišta. Glavni je oltar izmješten iz apside i pomaknut u središte svetišta, gdje se nekoć nalazio kanonički kor, premješten sada u apsidu. Dva bočna oltara premještena su iz apside u sjevernu odnosno južnu lađu katedrale. Međutim, to više nisu bili oltari iz vremena biskupa Osvalda i Luke, nego kasniji, barokni oltari iz 1703. godine, koji su još i danas u katedrali. ${ }^{30}$

Za tri fragmenta ploče biskupa Luke, pronađena nakon potresa 1880. godine, koja je zagrebački prvostolni kaptol darovao Narodnom muzeju u Zagrebu, navodi se da su za Bolléove restauracije izbačena na dvorište da bi radnici preko njih lakše gurali tačke. ${ }^{31}$ Potres je, vjerojatno kao i posljednji iz 2020. godine, razbio dijelove podne obloge, pri čijem su se čišćenju i pripremi za novo popločavanje otkrili prvi fragmenti ploče. Nakon potresa 2020. novi fragmenti pronađeni su uzidani ispod popločenja svetišta otprilike nasuprot nekadašnjem oltaru sv. Luke, pokraj kojeg se nalazila grobnica.

Spajanjem dijelova ploče pronađenih nakon obaju potresa približavamo se njezinom izvornom obliku. Kipar Johannes Fiorentinus prikazao je biskupa Luku kao blago usnulog pokojnika položenoga na dno plitkog odra, obloženoga čvrstim platnom ili kožom, pribijenom za stijenke čavlićima. Biskupova je glava, prema običaju toga doba, meko položena na jastuk, presvučen dekoriranim damastom s kićankama na uglovima. ${ }^{32}$ Takav položaj glave i taj tip jastuka, više ili manje stiliziran, uobičajen je na bezbrojnim nadgrobnim pločama s likom pokojnika crkvenoga i svjetovnog staleža 15. i 16. stoljeća. ${ }^{33} \mathrm{Na}$ temelju ranije sačuvanih ulomaka znalo se da je u biskupovu podnožju bila natpisna ploča u obliku rimskih tabulae ansatae, kakve su bile omiljene u doba humanizma i renesanse, s uklesanim natpisom koji je, kako smo vidjeli, zabilježio već Levaković. Naime, jedan od tri sačuvana ulomka iz Hrvatskoga povijesnog muzeja upravo je lijevi dio natpisne ploče. Zahvaljujući novim nalazima, gotovo se u potpunosti može rekonstruirati ne samo čitav biskupov lik, nego i natpisna ploča koju je umjetnik iluzionistički prikazao tako kao da doslovno leži u lijesu pod biskupovim nogama. Novi nalaz otkrio je gotovo čitavo biskupovo tijelo u potpunom ornatu. Sad se može vidjeti da biskupu Luki na prsima leži raspelo s trolisnim završetcima krakova u čijoj je sredini još jedan manji, plitko klesani križ. Raspelo pripada tipu pacifikala (raspela za blagoslov i ljubljenje) sa zvonolikim stalkom koji počiva na dlanu pokojnikove lijeve ruke, dok ga desna ruka priljubljuje uz njegovo tijelo. U sredini raspela uklesano je pravilno romboidno udubljenje, u kojem je možda bio učvršćen brončani umetak Kristova korpusa.

Novi nalaz otkrio je i jedan ikonografski detalj koji nešto više govori o samom biskupu Luki i njegovoj osobnoj pobožnosti. Naime, preko bogato vezenoga brokatnog križa misnice, ispod biskupovih prekriženih dlanova, leži veliki medaljon, prikazan u plitkom reljefu, obrubljen dragim kamenjem i biserjem, na kojem je prikazan Čovjek Boli - imago pietatis (sl. 3). Medaljon je lagano zakošen u odnosu prema misnici, na kojoj je nešto niže izvezen medaljon s kasnogotičkim Isusovim monogramom. Ispod Isusova monograma na misnici je izvezen i Marijin monogram AM s inicijalima u rimskoj kapitali. Medaljon s imago pietatis visi na debeloj vrpčastoj ogrlici koja se spušta s biskupova vrata, prolazi ispod križa i nestaje iza pokojnikovih dlanova.

Zbog izvanredne omiljenosti i goleme važnosti u kasnosrednjovjekovnoj i renesansnoj sakralnoj ikonografiji motiv imago pietatis na prsima pokojnoga biskupa Luke zaslužuje nešto iscrpniji osvrt. Ovdje se on pojavljuje u tipu izmučenog Krista prikazanoga nad grobnom rakom iz koje se diže gornji dio njegova tijela s uzdignutim rukama, dlanova okrenutih prema promatraču kako bi se vidjele rane i glavom prignutom na prsa, okrunjenom trnovom krunom. Anatomija Isusova tijela, od duge valovite kose koja mu pada iza ramena, preko crta lica, do prsa i uvučenog abdomena, razgovjetno se razabire. ${ }^{34}$ Dlanovi obiju ruku pokazuju rane od čavala, a ispod desnoga prsnog luka vidljiva je rana od koplja. Takav tip Čovjeka Boli s uzdignutim rukama najčešće se susreće na likovnim djelima sjevera Europe, mnogo rjeđe u Italiji odnosno u Dalmaciji, gdje prevladava tip s rukama prekriženim ispred trbuha ili prsa. ${ }^{35}$ Zagrebačka ikonografska varijanta uklapa se u sjevernjačku tradiciju koju, primjerice, predstavlja Čovjek Boli s uzdignutim rukama na Dürerovu bakrorezu nastalom oko 1500. godine (sl. 4). ${ }^{36}$ Isusov lik na medaljonu biskupa Luke kao da kopira gornji dio Isusova tijela s Dürerova bakroreza. Jednako tako on se uklapa u brojne prikaze Isusa kao Čovjeka Boli na popularnim slikama, grafikama i reljefima kojima je tema Misa sv. Grgura. Često se na takvim prikazima gornji dio oltara pred kojim papa Grgur Veliki služi misu pretvara u otvoreni sarkofag s Isusom koji uzdignutih ruku pokazuje svoje rane. ${ }^{37}$ Prikazi Čovjeka Boli u različitim ikonografskim inačicama bili su vrlo česti u svim kasnosrednjovjekovnim vizualnim medijima. U hrvatskoj likovnoj baštini oni su obilno zastupljeni na području jadranske Hrvatske, uključujući Istru. Na sjeveru sačuvani su primjeri mnogo rjeđi, no treba imati na umu da su mnogi nestali u povijesnim mijenama. Primjerice, u zagrebačkoj katedrali nalazila se na oltaru Sv. Trojstva kao dio veće oltarne cjeline jedna imago pietatis s likom Čovjeka Boli kojeg sa svake strane podupire po jedan anđeo. ${ }^{38}$ To je tip koji se u literaturi obično označava kao Pietà s anđelima. ${ }^{39}$ Oltar Sv. Trojstva nestao je iz katedrale, ali još uvijek je sačuvan misal zagrebačkog biskupa Osvalda Tuza, koji se obično naziva Misal Dominika Kálmáncsehija, iluminiran oko 1480. godine, $\mathrm{u}$ kojem je $\mathrm{u}$ inicijalu $\mathrm{T}$ na početku kanona mise ( $\mathrm{Te}$ 


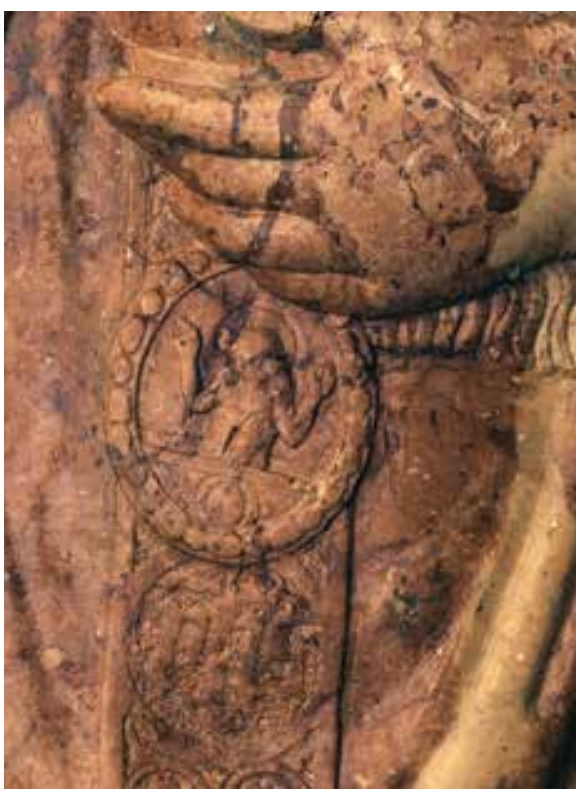

3. Medaljon (enkolpion) s likom Čovjeka boli Medallion (encolpion) with the image of the Man of Sorrows

igitur...) naslikana imago pietatis s likom Čovjeka Boli koji se prepoznaje kao inačica Euharistijskoga Krista iz Mise sv. Grgura (sl. 5). ${ }^{40}$ Njemu je vrlo slična freska s likom Čovjeka Boli preostala od kasnogotičkoga zidnog oslika župne crkve u Donjoj Stubici iz približno istog vremena. ${ }^{41}$ Tih nekoliko primjera ukazuje na to da je ikonografski motiv Čovjeka Boli na prijelazu15. u 16. stoljeće bio raširen i omiljen u Zagrebačkoj biskupiji u različitim sakralnim i liturgijskim funkcijama. Nadgrobna ploča biskupa Luke svjedoči i o njegovoj uporabi u sepulkralnoj ikonografiji.

Kao simbolička abrevijatura Isusove žrtve, otkupljenja i obećanja vječnog života onima koji u njega vjeruju, imago pietatis postaje već u kasnom srednjem vijeku čestom ikonografskom sastavnicom nadgrobnih spomenika, kako u Italiji, tako i onkraj Alpa. ${ }^{42} \mathrm{U}$ Dalmaciji nalazimo je na jednom reljefu iz Zadra, pripisanom Pavlu iz Sulmone. Pretpostavlja se da je pripadao grobnici Tome de Rose, opata sv. Krševana u Zadru, koji je umro 1389. godine. ${ }^{43}$ In situ sačuvana je na nadgrobnom spomeniku senjskog biskupa Ivana de Cardinalibusa iz 1392. godine, koji je također izradio Pavao iz Sulmone. ${ }^{44}$ $\mathrm{U}$ oba navedena slučaja mrtvo Isusovo tijelo nad sarkofagom pridržavaju Bogorodica i sv. Ivan. U sklopu kršćanske soteriologije simbolika Čovjeka Boli čvrsto je povezana s otajstvom otkupljenja i ulogom Isusa kao »žrtve pomirnice za naše grijehe« (1 Iv 4,10). U konkretnoj srednjovjekovnoj pobožnosti ona se za pojedinca pretače u mogućnost oprosta grijeha i izbavljenja iz čistilišta. Prema raširenoj pobožnoj praksi, meditacija ili molitva nad prikazom Mise sv. Grgura, u čijem je središtu lik imago pietatis, jamčila je oslobođenje od čistilišta za određeni broj godina. ${ }^{45}$ Jedno od mnogih svjedočanstava tom uvjerenju donosi drvorez s prikazom Mise sv. Grgura u kasnosrednjovjekovnoj kronici Jakoba Twingera, koju je dopunio i tiskao Johann Bämler u Augsburgu 1476. godine (sl. 6). ${ }^{46}$ Zajedno sa sličicom otisnut je i zapis

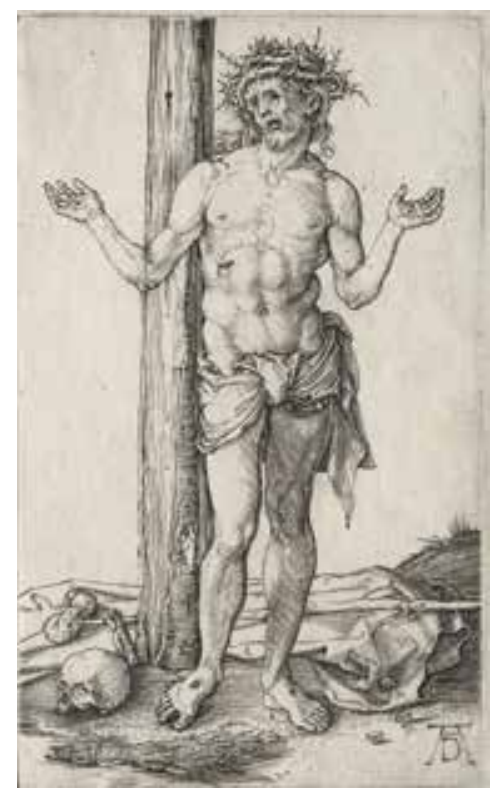

4. Albrecht Dürer, Čovjek boli, bakrorez, oko 1500.

Albrecht Dürer, The Man of Sorrows, copperplate engraving, ca. 1500

o indulgenciji kojim se onome tko časti sličicu i pred njom izmoli Oče naš jamči oprost muka u čistilištu u trajanju od 168 godina. ${ }^{47}$ Tome treba pribrojiti još 258 godina oprosta što su ih odobrili 43 pape i 1600 dana koje dodjeljuje 40 biskupa. U pobožnoj ekonomiji otkupljenja od grijeha, koja je težila umanjivanju kazni u čistilištu, te su stvari u srednjem vijeku imale veliko značenje. Kao zorna evokacija same srži otkupljenja prikaz Čovjeka Boli istodobno je podsjetnik na Isusovu žrtvu i djelatno sredstvo izbavljenja grešnika od muka u čistilištu. Biskup Luka vjerojatno je još za života posjedovao medaljonski privjesak Čovjeka Boli, koji mu je pružao nadu u skraćenje čistilišnih muka i s kojim je in effigie htio ostati sjedinjen u vječnom počinku, smatrajući ga svojevrsnim zalogom za spasenje vlastite duše.

Imago pietatis na medaljonskom privjesku pokojnoga zagrebačkog biskupa vizualno je svjedočanstvo uporabe medaljona u stvarnom životu crkvenog dostojanstvenika, analogne uporabi tzv. enkolpiona - medaljona s prikazom raspeća ili likom Bogorodice, osobito uvriježenoga u Istočnoj crkvi. ${ }^{48}$ $\mathrm{Na}$ sačuvanim nadgrobnim spomenicima s područja Ugarskoga Kraljevstva u kasnome srednjem vijeku jedan enkolpion, tj. medaljon s prikazom Raspeća, posvjedočen je na grobnoj ploči kardinala i ostrogonskog nadbiskupa Dénesa Szécsija (umro 1465.), sačuvanoj u katedrali u Ostrogonu. ${ }^{49}$ Enkolpion s prikazom imago pietatis, kakav posjeduje ploča biskupa Luke, izniman je ne samo u sklopu hrvatske nego i srednjoeuropske sepulkralne ikonografije. ${ }^{50}$ Kao zanimljivu ikonografsku usporednicu valja spomenuti zlatni medaljon s imago pietatis na triptihu Nikole Božidarevića u crkvi Gospe od Danača u Dubrovniku početkom 16. stoljeća. Medaljon služi kao kopča raskošnog plašta kojim je ogrnut sv. Grgur papa, pa utoliko nagoviješta funkciju sličnu enkolpionu. ${ }^{51}$ Dakako, na Božidarevićevoj slici imago pietatis izravno je povezan s prikazanim svetim papom Grgurom i njegovom 


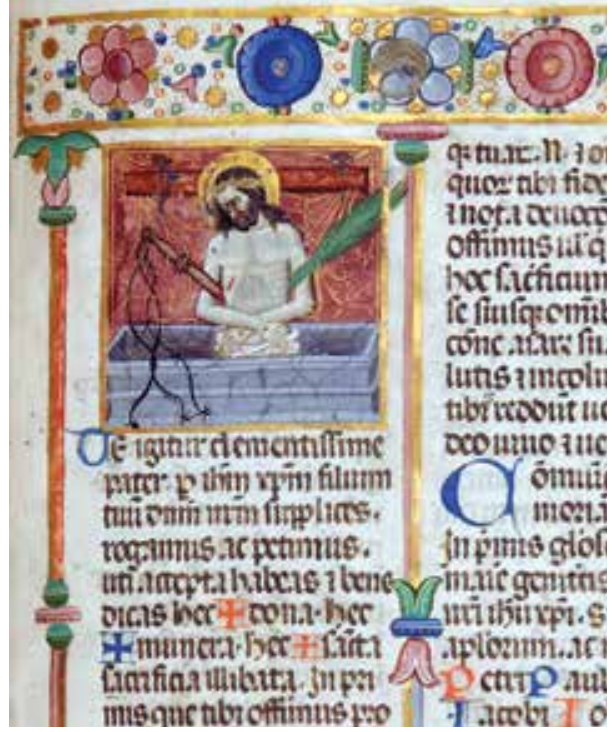

5. Čovjek Boli s oruđem muke (arma Christi) na početku misnoga kanona (Te igitur), Misal biskupa Osvalda Tuza (poznat i kao misal Dominika Kálmáncsehija), oko 1480., Zagreb, Riznica katedrale

The Man of Sorrows with the instruments of Passion (arma Christi) at the beginning of the Mass Canon (Te igitur), Missal of Bishop Oswald Tuz (also known as the Missal of Dominik Kálmáncsehi), ca. 1480, Zagreb, Treasury of the Cathedral

vizijom euharistijskoga Krista kao Čovjeka Boli, dok je na ploči biskupa Luke taj motiv izrazito personaliziran i predočen u obliku enkolpiona u kojem su sabrani simbolički aspekti devocionalne prakse i eshatologijskih očekivanja njegova vlasnika.

Nažalost nije ostao sačuvan grb biskupa Luke izliven u mjedi, pričvršćen u podnožju nadgrobne ploče, kako ga opisuje Levaković. U heraldičkom smislu on je bio sličan grbovima na drugim spomenicima i predmetima za čiju je narudžbu zaslužan biskup Luka, primjerice u tiskanom Misalu iz 1511. godine, na biskupovu pastoralu, srebrnoj škropionici za svetu vodu i na pax - pločici u Riznici katedrale, odnosno na grbu s pročelja franjevačke crkve u Kloštar Ivaniću, datiranom 1508. godinom. ${ }^{52}$ Njegov heraldički štit podijeljen je horizontalno po sredini, pri čemu se u gornjem dijelu nalazi poprsje grifona, a u donjem kruna. Među nadgrobnim pločama ugarskih dostojanstvenika iz tog vremena nema ni jedne s mjedenim grbom. Međutim, još iz ranijeg razdoblja srednjeg vijeka poznati su primjeri apliciranja mjedenih natpisnih slova $\mathrm{u}$ kamene nadgrobne ploče. Vodeći mađarski stručnjak za sepulkralnu plastiku Pál Lővei dokumentira nekoliko takvih primjera počevši od jedne ploče iz 13. stoljeća, poznate samo prema kasnijem opisu. ${ }^{53} \mathrm{U}$ humanističkim krugovima oko kralja Matije Korvina kombinacija crvenog kamena (po uzoru na carski porfir) i natpisa brončanim slovima rimske kapitale po uzoru na hramove, javne građevine, poslije i crkve Rimskoga Carstva, imala je snažno simboličko značenje i visoku reprezentativnu vrijednost. Predmeti umjetničkog obrta i kiparstva u bronci, nabavljeni u Italiji, bili su visoko cijenjeni u kraljevu dvorskom okruženju. Sam Matija Korvin pobrinuo se za njihovu izradu u Ugarskoj. ${ }^{54} \mathrm{U}$ tom značenjskom sklopu

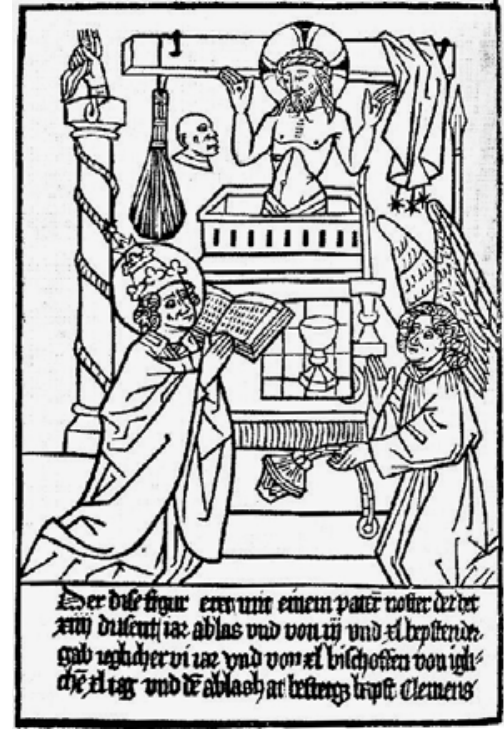

6. Misa sv. Grgura, drvorez sa zapisom o indulgenciji u kasnosrednjovjekovnoj kronici Jakoba Twingera, dopunio i tiskao Johann Bämler, Augsburg, 1476.

Mass of St Gregory, woodcut with a record of indulgence in the late medieval chronicle of Jakob Twinger, supplemented and printed by Johann Bämler, Augsburg, 1476

visoke reprezentativnosti tumači se i kasniji posvetni natpis u znamenitoj kapeli kardinala Tome Bakača u Ostrogonu iz 1520. godine, izrađen od pozlaćenih brončanih slova..$^{55}$ No zagrebačkom slučaju puno je bliža nadgrobna ploča ugarskoga palatina Stjepana Zapolje iz 1499. s likom pokojnika, jedan od najzahtjevnijih primjeraka te vrste u tadašnjoj Ugarskog. ${ }^{56} \mathrm{Na}$ njoj je iznad glave ležećeg viteza u oklopu na zastavi pričvršćen medaljon od pozlaćene bronce s likom jednoroga - amblemske životinje iz Zapoljina grba. Do njegovih nogu anđeli drže grbovne štitove na kojima su nekoć bili heraldički umetci izrađeni od bronce, no oni su nestali.

U tom ambijentu visoke kulturne reprezentacije valja sagledavati narudžbu nadgrobne ploče biskupa Luke, jednoga od najzaslužnijih biskupa u kulturnoj povijesti zagrebačke Crkve. Sudeći osobito po motivu imago pietatis kao promišljenom i osobnom ikonografskom dodatku pokojnikovu liku, možemo s većom sigurnošću pretpostaviti da je ploču za svoju grobnicu naručio sam biskup još za života. Po opisanim glavnim obilježjima: poliranom crvenom kamenu (često označavanom kao mramor) koji evocira porfir rimskih carskih sarkofaga, s natpisnom pločom u obliku tabula ansata, po liku preminuloga u punome biskupskom ornatu, po grbu izrađenom u bronci, po izvrsnome kiparskom radu firentinskog majstora, kao i po personaliziranome ikonografskom dodatku medaljona s likom Čovjeka Boli, nadgrobna ploča biskupa Luke od Segeda pripada skupini najreprezentativnijih grobnih monumenata na tlu nekadašnjega Ugarskog Kraljevstva. Za sjevernu Hrvatsku i Zagrebačku (nad)biskupiju ona je prvorazredni spomenik renesansne umjetnosti, na kojem se humanistički duh isprepleće s tradicionalnom simbolikom eshatoloških očekivanja pobožnoga biskupa. 


\section{Bilješke}

1

O tome vidjeti: http://www.zg-nadbiskupija.hr/dokumenti/aktualnosti/pronadjeni-ostaci-nadgrobne-ploce-biskupa-baratina, pripremila Veronika Novoselac (28. 11. 2020.).

\section{2}

Izložba je bila otvorena od 18. svibnja do 14. lipnja 2020., autor idejne koncepcije izložbene instalacije bio je muzejski savjetnik Boris Mašić. Informaciju o izložbi vidjeti na: http://www.mgz.hr/ hr/izlozbe/izlozbena-instalacija-muzejski-zivot-u-doba-pandemije-i-potresa,1584.html (28. 11. 2020.).

\section{3}

Prvi ih je opširno opisao JOSIP BRUNŠMID, Kameni spomenici Hrvatskog narodnog muzeja u Zagrebu, Vjesnik Hrvatskog arheološkog društva, 12 (1912.), 183-185. Za suvremeni opis vidjeti: MIRKO VALENTIĆ - LADA PRISTER, Hrvatski povijesni muzej. Zbirka kamenih spomenika, Zagreb, 2002., 26 i d. Tu se navodi da je ulomak s biskupovim likom u Narodni muzej dopremljen 1907. godine, a druga dva ulomka nakon 1925. kao dar zagrebačkog Kaptola nakon preuređenja zagrebačke katedrale.

\section{4}

Zahvaljujem Uredu za kulturna dobra Zagrebačke nadbiskupije i njegovom voditelju vlč. Vladi Mikšiću za dopuštenje da se fragmenti pregledaju i fotografiraju. Autor fotografija je Paolo Mofardin s Instituta za povijest umjetnosti.

\section{5}

Kao orijentir navodim nekoliko novijih bibliografskih jedinica: JÓLAN BALOGH, Későrenaissance kőfaragó műhelyek [Kamenarske radionice kasne renesanse], Ars Hungarica, 2 (1974.), 42; LELJA DOBRONIĆ, Renesansa u Zagrebu, Zagreb, 1994., 74; PÁL LÖVEI, Salzburg und Gran versus Krakau, Gnesen und Wilna: Die Lieferung des Rotmarmors im Fernhandel Mitteleuropas, u: Die Jagiellonen. Kunst und Kultur einer europäischen Dynastie an der Wende zur Neuzeit, Nürnberg, 2002., 411-421, posebno str. 414 i d., s osvrtom na raniju literaturu; MILAN PELC, Ugarske kiparske radionice i renesansa u sjevernoj Hrvatskoj, Radovi Instituta za povijest umjetnosti, 30 (2006.), 67-71.

\section{6}

Vidjeti o tome MILAN PELC (bilj. 5), 67 i d., s pripadajućom literaturom o Johannesu Fiorentinusu i njegovim djelima.

\section{7}

Ulomci su sljedećih dimenzija: srednji dio tijela, $123 \times 75 \mathrm{~cm}$; lijevo rame, $40 \times 50 \mathrm{~cm}$; lijevi komad natpisne ploče, $43 \times 22 \mathrm{~cm}$; srednji/desni komad natpisne ploče $46 \times 60 \mathrm{~cm}$. Njihovim spajanjem s tri fragmenta u Hrvatskom povijesnom muzeju dobivaju se približne dimenzije čitave ploče od oko $220 \times 105 \mathrm{~cm}$, pri čemu je debljina na najispupčenijem dijelu oko $25 \mathrm{~cm}$.

8

O životu i zaslugama biskupa Luke vidjeti: ANDRIJA LUKINOVIĆ, Luka Baratin 1500-1510, u: Zagrebački biskupi i nadbiskupi (ur. Franko Mirošević), Zagreb, 1995., 223-227.

\section{9}

Pregled umjetničkih narudžbi biskupa Luke donosi LELJA DOBRONIĆ (bilj. 5), 59 i d.

10

Tu je atribuciju predložio GRGO GAMULIN, Dodatak za Gian Francesca da Tolmezzo, Peristil, 4 (1961.), 82-83. Do danas još nije provedeno temeljitije komparativno istraživanje koje bi ju potvrdilo ili opovrglo.
11

O ilustracijama misala vidjeti: TINE GERM, "Missale Zagrabiense" iz Narodne in univerzitetne knjižnice u Ljubljani, Zbornik za umetnostno zgodovino, 38 (2002.), 107-123.

12

O biskupu Osvaldu i prvome tiskanom zagrebačkom brevijaru vidjeti: STJEPAN RAZUM, Osvaldo Thuz de Szentlászló Vescovo di Zagabria, 1466-1499, doktorska disertacija, Rim, Pontificia universitas Gregoriana, 1995., 153-160, 793-846.

13

Vidjeti o tome katalog izložbe Mathias Corvinus und die Renaissance in Ungarn 1458-1541, Schallaburg, 1982., a u njemu osobito studiju JOLÁN BALOGH, Die Kunst der Renaissance in Ungarn, 81-107.

14

Za sudjelovanje biskupa Luke u kulturnoj modi renesanse i njezinom oponašanju antike vidjeti: ÁRPÁD MIKÓ, All'antica djela i njihovi stvaraoci u Budimu i Zagrebu za Matije Korvina i Jagelovića (1480 1526), u: Hrvatska / Mađarska. Stoljetne književne i likovno-umjetničke veze, Zagreb, 1995., 53-60; također ÁRPÁD MIKÓ, Lukács Szegedi, the Bishop of Zagreb and the Arts. Paths of the all'antica style in the Kingdom of Hungary in the early $16^{\text {th }}$ century, $\mathrm{u}$ : Bonum ut pulchrum. Essays in Art History in Honour of Ernö Marosi on His Seventieth Birthday (ur. Livia Varga i dr.), Budapest, 2010., 443-456.

15

Vidjeti o tome ERWIN PANOFSKY, The Tomb Sculpture, Four Lectures on Its Changing Aspects from Ancient Egypt to Bernini, New York, 1964., 61-62. O memorijskom karakteru srednjovjekovnih grobnica usp. ROBERT MARCOUX, Memory, Presence and the Medieval Tomb, u: Revisiting The Monument: Fifty Years since Panofsky's Tomb Sculpture (ur. Ann Adams - Jessica Barker), London, 2016., 49-67.

16

Vidjeti o tome ARNOLD ANGENENDT, Das Grab als Haus des Toten, u: Grabmäler. Tendenzen der Forschung an Beispielen aus Mittelalter und früher Neuzeit (ur. Wilhelm Maier - Wolfgang Schmid - Michael Viktor Schwarz), Berlin, 2000., 11-29.

17

Vidjeti o tome HANS KÖRNER, Grabmonumente des Mittelalters, Darmstadt, 1997., 111 i d.

18 Nadgrobne ploče zagrebačkih biskupa opisane su u djelima sljedećih starijih pisaca: RAFAEL LEVAKOVIĆ, Historiola Episcopatus Zagrabiensis, između 1638. i 1640., rukopis u Arhivu Hrvatske akademije znanosti i umjetnosti, sign. IV. c. 15; transkripcija teksta: RAFAEL LEVAKOVIĆ, Descriptio ecclesiae Zagrabiensis, $\mathrm{u}$ Zbornik o Rafaelu Levakoviću (ur. Pavao Knezović), Zagreb, 2010. 387-394; TOMA KOVAČEVIĆ, Catalogus praesulum zagrabiensium, početak 18. stoljeća, rukopis u Arhivu Hrvatske akademije znanosti i umjetnosti, sign. II. A. 70; BALTAZAR ADAM KRČELIĆ, Historiarum cathedralis ecclesiae Zagrabiensis partis primae tomus I, Zagrabiae, typis Antonii Jandera, 1769.; pretisak Zagreb, 1994., hrv. prijevod: Povijest Stolne crkve zagrebačke, Zagreb, 1994.; DANIEL FARLATI, Illyricum Sacrum, sv. 5, Venezia, 1775. ; IVAN KRSTITELJ TKALČIĆ, Prvostolna crkva zagrebačka nekoć i sada, Zagreb, 1885.; IVAN KUKULJEVIĆ SAKCINSKI, Nadpisi sredovječni i novovjeki na crkvah, javnih i privatnih sgradah i t.d. u Hrvatskoj i Slavoniji, Zagreb, 1891., br. 1129.

19

TOMA KOVAČEVIĆ (bilj. 18), fol. 81a., piše da je tom prigodom uklonjena i nadgrobna ploča biskupa Petra Petretića: Sed qui anno 
1703, cum caeterorum Antistitum monumentis, dum Sanctuarium marmore sterneretur, sublatus est (koja je 1703. godine, kad se svetište popločavalo mramorom, uklonjena zajedno s pločama ostalih biskupa).

20

To sa žaljenjem konstatira GJURO SZABO, Prilozi za građevnu povijest zagrebačke katedrale, Narodna starina, sv. 8. br. 19 (1929.), 74, iznoseći kao primjer vandalizma starijih vremena upravo nadgrobnu ploču biskupa Luke.

21

O smještaju oltara u katedrali jasnu i preciznu sliku daje nacrt Franje Klobučarića nastao 1792. - 1794. godine. Vidjeti: LELJA DOBRONIĆ, Biskupski i kaptolski Zagreb, Zagreb, 1991., 49.

22

IVAN KRSTITELJ TKALČIĆ (bilj. 18), 57. Taj oltar izgorio je 1624. godine, a na njegovu mjestu postavljen je 1632. novi oltar. Potom je 1703. i taj oltar uklonjen te postavljen novi mramorni oltar sv. Luke. Pri obnovi katedrale nakon potresa 1880. on je premješten u kapelu Blažene Djevice Marije, tj. u južnu apsidu katedrale.

23

Petrografska analiza ploče biskupa Luke provedena je posredovanjem dr. Pala Lőveia 2005. u Geokemijskom laboratoriju Mađarske akademije znanosti u Budimpešti. Vidjeti: MILAN PELC (bilj. 5), 77.

\section{4}

Prijepis čitava Levakovićeva teksta donosi JOSIP BRUNŠMID (bilj. 3), 184. Kako je rečeno, ploču su in situ mogli vidjeti jedino Levaković i Kovačević. Prema njima opise ploče i prijepise natpisa prenose BALTAZAR ADAM KRČELIĆ (bilj. 18) 240; DANIEL FARLATI (bilj. 18), 516; IVAN KRSTITELJ TKALČIĆ (bilj. 18), 57; IVAN KUKULJEVIĆ SAKCINSKI (bilj. 18), br. 1129.; MIRKO VALENTIĆ - LADA PRISTER, (bilj. 3), 27. Prijepisi se razlikuju u sitnim pojedinostima. Ovdje donosim natpis usklađen s novopronađenim fragmentima.

\section{5}

Prve dvije riječi natpisa ne vide se zbog oštećenja. Zanimljivo je da u svojim prijepisima Levaković i Kovačević završavaju riječ VENERABILIS skraćeno kao VENERABIL s tri točke. Na novopronađenom ulomku ne može se razabrati je li taj dio riječi bio uklesan skraćeno ili se izgubio zbog oštećenja ploče.

26

Levaković u svom prijepisu ne bilježi riječ SUI već stavlja tri točke. Kovačević bilježi riječ SUI. BALTAZAR ADAM KRCELIĆ (bilj. 18), 207; DANIEL FARLATI (bilj. 18), 516; IVAN KRSTITELJ TKALČIĆ (bilj. 18), 57, na ovom mjestu bilježe riječ SACRI. Na novopronađenom ulomku sačuvalo se samo prvo slovo $S$.

27

Levaković i Kovačević bilježe čitavu riječ SECUNDUS, na novopronađenom ulomku vide se samo prva tri slova SEC.

\section{8}

Na pronađenom ulomku oštećen je drugi dio riječi OCTOBRIS. Kovačević bilježi čitavu riječ.

29

Nešto je drukčiji prijevod Zlatka Šešelja u BALTAZAR ADAM KRČELIĆ (bilj. 18), 240:

Ovdje je položen Luka poštovan biskup.

Crkvi presvetoj toj bio je dika i sjaj.

Pobožan bio je uvijek, nitko mu krepošću ravan

Zaslugom svojom je, znaj, dosego zvjezdani svod.

Natpis kratko spominje MIRJANA MATIJEVIĆ SOKOL, Epitafi srednjega vijeka: "knjige života i smrti", u: Smrt u opusu Vladana
Desnice i europskoj kulturi: poetički, povijesni i filozofski aspekti. Zbornik radova s medunarodnoga znanstvenog skupa Desničini susreti (ur. Drago Roksandić - Ivana Javorina Cvijović), Zagreb, 2017., 392. Pritom ističe sintagmu iz natpisa LUXQUE DECUSQ (ures i svjetlo), kao epitet za istaknute muževe.

30

O njima vidjeti: LELJA DOBRONIĆ (bilj. 21), 50.

31 Vidjeti u: MIRKO VALENTIĆ - LADA PRISTER (bilj. 3), 27.

32

JOSIP BRUNŠMID (bilj. 3), 183, smatra da se radi o kožnoj podstavi škrinje, »koja kao da je na više mjesta čavlima prikovana«. Za jastuk također piše da je od prešane kože!

33

Za primjere u Hrvatskoj vidjeti: MILAN PELC, Renesansa. Povijest umjetnosti u Hrvatskoj, Zagreb, 2007., 304-319.

34

Ti će se detalji još bolje vidjeti nakon finog čišćenja ostataka vapna i prljavštine.

35

O tipologiji imago pietatis postoji opsežna literatura. Radi orijentacije vidjeti temeljnu studiju: ERWIN PANOFSKY, "Imago pietatis": Ein Beitrag zur Typengeschichte des "Schmerzensmanns" und der "Maria Mediatrix", u: Festschrift für Max J. Friedländer zum 60. Geburtstag, Leipzig, 1927., 261-308; GERT VON DER OSTEN, Der Schmerzensmann. Typengeschichte eines deutschen Andachtsbildwerkes von 1300 bis 1600, Berlin, 1935.; HANS BELTING, Das Bild und sein Publikum im Mittelalter. Form und Funktion früher Bildtafeln der Passion, Berlin, 1981.; ANCHISE TEMPESTINI, L'iconografia del Cristo morto nelle regioni adriatiche occidentali, u: Giovanni Santi. Atti del Convegno internazionale di studi (ur. Ranieri Varese), Milano, 1995., 171-176; CATHERINE R. PUGLISI - WILLIAM L. BARCHAM (ur.), New Perspectives on the Man of Sorrows, Kalamazoo, 2013.; CATHERINE PUGLISI, The Man of Sorrows in Venetian Art, u: Passion in Venice: Crivelli to Tintoretto and Veronese, katalog izložbe (ur. Catherine Puglisi - William Barcham), New York, 2011., 10-27.

36

Vidjeti: MITCHELL B. MERBACK, Man of Sorrows in Northern Europe: Ritual Metaphor and Therapeutic Exchange, u: Passion in Venice: Crivelli to Tintoretto and Veronese (bilj. 35), 95. Dürer je u grafici izradio niz različitih prikaza Čovjeka Boli koji zorno pokazuju njegovu popularnost u ikonografiji oko 1500. godine. Mnogo je primjera u različitim tipološkim inačicama na stranici https://www.bildindex.de pod natuknicom Schmerzensmann, s informacijama o preko 1000 djela (2. 4. 2021.).

37

Za primjere vidjeti studije u zborniku radova ANDREAS GORMANS - THOMAS LENTE (ur.), Das Bild der Erscheinung: die Gregorsmesse im Mittelalter (KultBild 3), Berlin, 2007.

38

Oltar je 1515. podigao zagrebački kanonik i vaškanski arhiđakon Grgur. Vidjeti: IVAN KRSTITELJ TKALČIĆ (bilj. 18), 83 i d. Slika je oko 1522. zabilježena i opisana u inventaru oltara Sv. Trojstva koji se nalazio u katedrali kraj srednjeg stupa južne lađe katedrale: Item interius in tabula est imago Pietatis, habens in qualibet sui parte imagynem angeli circa brachia. Vidjeti: IVAN KRSTITELJ TKALČIĆ, Povjestni spomenici slob. kralj. grada Zagreba, sv. 11, Zagreb, 1905., 215. Za oltar sv. Trojstva kanonik Grgur dao je izraditi klecalo $s$ tri sjedala koja su imala naslone s intarzijama. Na jednoj od intarzija bila je prikazana Misa sv. Grgura. Oltar i 
klecalo opisuje IVAN KRSTITELJ TKALČIĆ (bilj. 18), 83-87 i d., prema dokumentima u kaptolskom arhivu.

\section{9}

Vidjeti članak Engelpietà u: Reallexikon der deutschen Kunstgeschichte RDK V, 601-621 (1960), autor Gert von der Osten, dostupno online: https://www.rdklabor.de/wiki/Engelpiet\%C3\%A0 (31. 3. 2021.).

40

O misalu vidjeti: EDITH HOFFMANN, Kőzepkori kőnyvkultúránk néhány fontos emlékéröl, Magyar Könyvszemle, 1-4 (1925.), 35 i d.; DRAGUTIN KNIEWALD, Zagrebački liturgijski kodeksi XI-XV. stoljeća, Croatia Sacra, 19 (1940.), 80 i d.; LELJA DOBRONIĆ (bilj. 5), 28 i d.

41

Vidjeti: MIRJANA REPANIĆ-BRAUN, Zidno slikarstvo, u: Umjetnička topografija Hrvatske. Krapinsko-Zagorska Županija (ur. Ivanka Reberski), Zagreb, 2008., 157 i d.

42

Rani je primjer sarkofag grobnice Cangrande I. della Scala, 1335., Verona, Santa Maria Antica. Vidjeti: CATHERINE R. PUGLISI - WILLIAM L. BARCHAM, Bernardino da Feltre, the Monte di Pietà and the Man of Sorrows: Activist, Microcredit and Logo, Artibus et Historiae, 29, No. 58 (2008.), 45. Vidjeti također online bazu podataka Bildindex der Kunst und Architektur, https://www. bildindex.de, pod natuknicom Schmerzensmann (1. 12. 2020.).

43

Vidjeti: IVO PETRICIOLI, Dva priloga zadarskoj umjetničkoj baštini, Prilozi povijesti umjetnosti u Dalmaciji, 25 (1985.), 85; EMIL HILJE, Još jedno djelo kipara Pavla iz Sulmone, Radovi Instituta za povijest umjetnosti, 27 (2003.), 39.

44

Vidjeti: EMIL HILJE (bilj. 43).

45

Zato je motiv duša iz čistilišta koje vape za izbavljenjem sastavnica mnogih prikaza Mise sv. Grgura. Usp. Bartholomäus Bruyn St. (1493? - 1555.) (škola), Misa sv. Grgura, oko 1515. Bösensell, Haus Alvinghof, Sammlung von und zur Mühlen, dostupan online: http://gregorsmesse.uni-muenster.de/objektanzeige.php? $\mathrm{ID}=33250$ \&einfach=bruyn\&currentQuery.x=12\&currentQuery. $y=8$ (18. 12. 2020.). Više komparativne slikovne građe vidjeti na mrežnim stranicama VW-Forschungsgruppe "Kulturgeschichte und Theologie des Bildes im Christentum": http://gregorsmesse. uni-muenster.de/impressum.html (19. 12. 2020.). O Misi sv. Grgura u kasnosrednjovjekovnoj pobožnosti vidjeti: PATRICIA STROHMAIER, Geschnitzt, gestickt, gemalt. Werkstrategien spätmittelalterlicher Andachtsbilder, Acta Historiae Artium Academiae Scientiarum Hungaricae, 59 (2018.), 143-172. Autorica, između ostaloga, analizira bakropis Majstora I. A. M iz Zwollea iz posljednje trećine 15. stoljeća na kojem je prikazana Misa sv. Grgura s dušama iz čistilišta s desne strane oltara. (str. 148 i d.).

46

Chronik von allen Kaisern, Königen und Päpsten: primjerak u Nürnbergu, Germanisches Nationalmuseum, Inc. Quart 36186. Vidjeti: http://gregorsmesse.uni-muenster.de/objektanzeige. php? $\mathrm{ID}=33448 \&$-skip $=190 \&$ currentQuery=Show (19. 12. 2020.).
47

Natpis na njemačkom glasi: Der dise figur eret mit einem pater noster der hat | xiiij dusent iar ablas vnd von iij vnd $\mathrm{xl}$ bepsten der $\mid$ gab ieglicher vi iar vnd von $x l$ bischoffen von igli= $\mid$ che $(m)$ $\mathrm{xl}$ tag vnd $\mathrm{de}(\mathrm{n})$ ablas hat bestet(i)g(t) bapst Clemens'.

48

Za enkolpion vidjeti: HANS-RUDOLF PETERS, Enkolpion, u: Reallexikon zur Deutschen Kunstgeschichte, Bd. V (1961.), Sp. 737; in: RDK Labor, https://www.rdklabor.de/w/?oldid=88801 (15.02.2021).

49

Vidjeti: LÍVIA VARGA - PÁL LÖVEI, Funerary Art in medieval Hungary, Acta Historiae Artium Academiae Scientiarum Hungaricae, 35 (1990.-1992.), 115-167, 140 i d. Za informacije o nadgrobnim pločama u Ugarskoj zahvaljujem dr. Pálu Lőveiu. S područja Ugarskoga Kraljevstva iz toga doba valja spomenuti i nadgrobnu ploču naslovnoga kninskog biskupa Bricciusa Egerváryja iz 1515. u crkvi sv. Katarine u Egerváru, kojemu oko vrata visi mali kružni medaljonski relikvijar s poklopcem. Vidjeti: Mathias Corvinus und die Renaissance in Ungarn 1458-1541, katalog izložbe, Schallaburg, 1982., 691 i d. LÂSZLÓ ÉBER, Egerváry Bereczk síremléke, Archaeologiai Értesitö, 35 (1915.), 289-282, njem. sažetak u dodatku, str. 70-71, tabla 62, naziva taj privjesak također encolpium.

50

Među više od 1000 primjera koje dokumentira Bildindex (bilj. 42) nema nijednog sličnog.

51

Vidjeti: RADOSLAV TOMIĆ, Slike Lovre Dobričevića i Nikole Božidarevića na Dančama, u: Crkva i samostan sv. Marije na Dančama (ur. Luko Paljetak - Katica Dabo), Dubrovnik, 2010., 142. Božidarević se mogao inspirirati reljefom imago pietatis na pax-pločici iz Madernove radionice. Jedna takva pločica sačuvana je u Koritima na Mljetu. Vidjeti: VINICIJE LUPIS, Pax - predočnica, Anali Zavoda za povijesne znanosti HAZU u Dubrovniku, 33 (1995.), 57.

52

O grbu iz Kloštar Ivanića vidjeti: KRASANKA MAJER JURIŠIĆ - IVAN JENGIĆ, Kameni grb biskupa Luke: povijesnoumjetnička analiza i restauratorski radovi, Godišnjak zaštite spomenika kulture Hrvatske, 37 (2013.), 173-182.

53

PÁL LÖVEI, Virtus, es, marmor, scripta. Red Marble and Bronze Letters, Acta Historiae Artium Academiae Scientiarum Hungaricae, 42 (2001.), 39-55, 49.

54

Vidjeti: Mathias Corvinus und die Renaissance in Ungarn 14581541 (bilj. 49), 313 i d.

55

PÁL LÖVEI (bilj. 53), 47.

56

PÁL LŐVEI (bilj. 53), 50 i d. Vidjeti opis i reprodukciju te nadgrobne ploče u Mathias Corvinus und die Renaissance in Ungarn 1458-1541. (bilj. 49), 683-684, sl. 19 (autorica Jolán Balogh). Ploča se nalazi u grobnoj kapeli obitelji Zapolja u katedrali sv. Martina, Spišská Kapitula, Slovačka. 


\title{
Summary
}

\author{
Milan Pelc
}

\section{Tombstone of Luka de Szeged (Luka Baratin), Bishop of Zagreb}

During the primary repairs of the damage caused by the earthquake that struck Zagreb and its surroundings on March 22, 2020, four stone fragments were found in the floor under the pavement in the cathedral apse and promptly identified as parts of the tombstone of Luka de Szeged, also known as Luka Baratin, Bishop of Zagreb from 1500 to 1510 . In the previous strong earthquake of 1880 , three fragments of the same tombstone had been found, the most impressive being the portrayed head of the late bishop in full sculpture (all three preserved in the Croatian History Museum). Initially, some local experts attributed this work to sculptor Giovanni Dalmata (Ivan Duknović), but recently the Italian sculptor Johannes Fiorentinus, whose workshop in Esztergom produced a number of monuments, primarily tombstones, for various commissioners in the Kingdom of Hungary and beyond, has been acknowledged as the author of the bishop's tombstone. The four new fragments found in the cathedral significantly complement our knowledge of the appearance and shape of the bishop's tombstone, confirming the artistic and material unity of its making, as well as its uniqueness within the group of similar tombstones produced in the Kingdom of Hungary at that time.

Bishop Luka de Szeged was in close contact with the royal court in Buda during the reign of Vladislaus II, where he held the distinguished service of the king's treasurer. Staying frequently in Buda, he came into direct contact with the cultural trends at the court and the Renaissance fashion that was spreading from Italy to the Kingdom of Hungary. Artists' workshops, in which Italian masters had the main say, were established to meet the needs of the royal palace, but they also received commissions from other dignitaries, primarily ecclesiastical and secular magnates who imitated the artistic tastes of the ruler and the court. Bishop Luka commissioned a tombstone for his grave located in a prominent place in the sanctuary of the ecclesia cathedralis, which depicted his figure in full ornate with the coat of arms and an appropriate inscription. Unfortunately, along with the tombstone of other bishops located in the cathedral sanctuary, it was removed during the installation of the new paving in 1703. The tombstones are mentioned in the descriptions of the Zagreb cathedral from the $17^{\text {th }}$ and $18^{\text {th }}$ centuries. The earliest description is that of Canon Rafael Levaković (around 1638), which also brings the tombstone inscription. Due to the finding of new fragments, the inscription can now be almost completely reconstructed:

[HIC SITV]S EST LVCAS PRAESVL VENERABIL[IS] ZAGRABIAE TEMPLI LVXQVE DECVSQ S[VI] or S[ACRI] QVI PIETATE PARENS NVLLI VIRTVTE SEC[VNDVS] ACCEPIT MERITIS ASTRA PARATA SVIS OBIIT ANNO MDX X' K(A)L. OC[TOBRIS]

The new find has revealed almost the entire lower part of the bishop's body in full ornate. It can now be seen that Bishop Luka has a pax on his chest, with three-leafed arm ends. In its centre, there is another, smaller and shallowly carved cross with a regular rhomboid recess, in which a bronze insert of
Corpus Christi may have been fixed. This detail coincides with the information from Levaković's description, according to which the bishop's coat of arms was made of brass and applied to a stone slab next to his right foot. Unfortunately, these bronze parts of the tombstone have been lost.

A newly revealed iconographic detail tells a little more about Bishop Luka and his personal piety. Over the richly embroidered brocade cross of the chasuble, under the bishop's palms, there is a large medallion encolpion, shown in shallow relief and bordered with gems and pearls, which depicts the Man of Sorrows - imago pietatis. The encolpion is slightly slanted in relation to the cross on the chasuble, below which there is an embroidered medallion with Christ's monogram IHS, and a little lower Mary's monogram with the initials AM in Roman capital letters. The encolpion with the imago pietatis hangs on a necklace that descends from the bishop's neck, passes under the cross, and disappears behind his palms. Judging by the depiction on the tombstone, Bishop Luka owned the encolpion with the Man of Sorrows while still alive, as it gave him hope to shortening his time in the Purgatory, and he wanted to remain united with it in effigie in his eternal rest, considering it a kind of token for the salvation of his soul. As for the preserved tombstones from the late medieval Kingdom of Hungary, a similar encolpion, i.e. medallion depicting the Crucifixion, is attested on the tombstone of Cardinal Dénes Szécsi, Archbishop of Esztergom (d. 1465), preserved in the Esztergom Cathedral. Another example is the tombstone of Briccius Egerváry, a titular Bishop of Knin, situated in the church of St Catherine in Egervár and dating from 1515, where the bishop is wearing a small circular medallion reliquary around his neck - an encolpion with a lid. However, an encolpion with the imago pietatis as that on the tombstone of Bishop Luka, is exceptional not only in Croatian, but also in Central European sepulchral iconography.

The medallion with the imago pietatis used as a personalized addition to the representation of the deceased indicates that the bishop commissioned the tombstone himself while still alive. With its main features just described - polished red stone (often indicated as marble) evoking the porphyry of Roman imperial sarcophagi, an inscription plate in the form of a tabula ansata, the image of the deceased in full episcopal ornate, the coat of arms wrought in bronze, exquisite sculptural work by a Florentine master, and the medallion with the Man of Sorrows as a personalized iconographic addition - the tombstone of Bishop Luka de Szeged belongs to the most representative sepulchral monuments known from the former Kingdom of Hungary. For northern Croatia and the (Arch)diocese of Zagreb, it is a first-class monument of Renaissance art, where the humanist spirit intertwines with the traditional symbolism of eschatological expectations of a pious bishop.

Keywords: Luka de Szeged (Luka Baratin), Bishop of Zagreb, tombstone, encolpion, imago pietatis 